\title{
Molecular cloning of the cDNA encoding follicle-stimulating hormone $\beta$ subunit of the Chinese soft-shell turtle Pelodiscus sinensis, and its gene expression
}

\author{
Jung-Tsun Chien ${ }^{\mathrm{a}, \mathrm{b}}$, San-Tai Shen ${ }^{\mathrm{a}}$, Yao-Sung Lin ${ }^{\mathrm{b}}$, John Yuh-Lin Yu ${ }^{\mathrm{a}, *}$ \\ a Endocrinology Laboratory, Institute of Zoology, Academia Sinica, Taipei, 115 Taiwan, ROC \\ ${ }^{\mathrm{b}}$ Institute of Ecology and Evolutionary Biology, College of Life Science, National Taiwan University, Taipei, 106 Taiwan, ROC
}

Received 9 July 2004; revised 22 December 2004; accepted 23 December 2004

\begin{abstract}
Follicle-stimulating hormone (FSH) is a member of the pituitary glycoprotein hormone family. These hormones are composed of two dissimilar subunits, $\alpha$ and $\beta$. Very little information is available regarding the nucleotide and amino acid sequence of FSH $\beta$ in reptilian species. For better understanding of the phylogenetic diversity and evolution of FSH molecule, we have isolated and sequenced the complementary DNA (cDNA) encoding the Chinese soft-shell turtle (Pelodiscus sinensis, Family of Trionychidae) FSH $\beta$ precursor molecule by reverse transcription-polymerase chain reaction (RT-PCR) and rapid amplification of cDNA end (RACE) methods. The cloned Chinese soft-shell turtle FSH $\beta$ cDNA consists of 602-bp nucleotides, including 34-bp nucleotides of the 5'-untranslated region (UTR), 396-bp of the open reading frame, and 3'-UTR of 206-bp nucleotides. It encodes a 131-amino acid precursor molecule of FSH $\beta$ subunit with a signal peptide of 20 amino acids followed by a mature protein of 111 amino acids. Twelve cysteine residues, forming six disulfide bonds within $\beta$-subunit and two putative asparagine-linked glycosylation sites, are also conserved in the Chinese soft-shell turtle FSH $\beta$ subunit. The deduced amino acid sequence of the Chinese soft-shell turtle FSH $\beta$ shares identities of $97 \%$ with Reeves's turtle (Family of Bataguridae), $83-89 \%$ with birds, $61-70 \%$ with mammals, $63-66 \%$ with amphibians and $40-58 \%$ with fish. By contrast, when comparing the FSH $\beta$ with the $\beta$-subunits of the Chinese soft-shell turtle luteinizing hormone and thyroid stimulating hormone, the homologies are as low as 38 and 39\%, respectively. A phylogenetic tree including reptilian species of FSH $\beta$ subunits, is presented for the first time. Out of various tissues examined, FSH $\beta$ mRNA was only expressed in the pituitary gland and can be up-regulated by gonadotropin-releasing hormone in pituitary tissue culture as estimated by fluorescence real-time PCR analysis.
\end{abstract}

(c) 2005 Elsevier Inc. All rights reserved.

Keywords: Follicle-stimulating hormone; cDNA cloning; Amino acid sequence; Chinese soft-shell turtle; Pituitary gland; Gonadotropin-releasing hormone; mRNA expression

\section{Introduction}

All vertebrate species are characterized by possession of a pituitary gland that secretes glycoprotein hormones-gonadotropins and thyrotropin, synthesized,

\footnotetext{
* Corresponding author. Fax: +886 227858059.

E-mail address: johnylyu@gate.sinica.edu.tw (J.Y.-L. Yu).
}

respectively, by gonadotrops and thyroptrops. There are two structurally and functionally distinct types of gonadotropin (GTH): luteinizing hormone (LH) and follicle-stimulating hormone (FSH). All three pituitary glycoprotein hormones are composed of two structurally dissimilar subunits, $\alpha$ and $\beta ; \alpha$ subunits are identical for all three glycoprotein hormones in a species, while $\beta$ subunits are specific and determine the hormonal activity and species specificity (Pierce and Parsons, 1981). The 
subunits are synthesized as separate proteins translated from different mRNAs expressed by different genes. Following glycosylation, they are associated by non-covalent bonding to form the biologically active hormone molecules. The main role of the $\alpha$ subunit is to confer biological action through the signal transduction pathway, and that of the $\beta$ subunit is to convey hormone and species specificity. Both subunits are needed for receptor interaction (Fox et al., 2001; Lapthorn et al., 1994; Ryan et al., 1987).

FSH functions together with $\mathrm{LH}$ to promote the growth and development of gonads, to control gametogenesis and to regulate gonadal endocrine functions (Moyle et al., 1994). The structure, function, and regulation of FSH molecules have been investigated most extensively in mammalian species (Moyle et al., 1994; Pierce and Parsons, 1981). The nucleotide sequences of cDNA and amino acids of FSH $\beta$ have been studied most in mammals and fish, relatively less in birds and amphibians, and least in reptiles. The cDNAs and deduced peptide sequence of the $\mathrm{FSH} \beta$ molecule are available for at least 16 species of mammal (Belov et al., 1998; Fujiki et al., 1978; Jameson et al., 1988; Kato, 1988; Koura et al., 2004; Kumar et al., 1995; Lawrence et al., 1997; Liao et al., 2003; Maurer, 1987; Sairam et al., 1981; Schmidt et al., 1999), 28 species of fish (Degani et al., 2003; Han et al., 2004; Hassin et al., 1995; Itoh et al., 1988; Jackson et al., 1999; Kajimura et al., 2001; Kato et al., 1993; Lin et al., 1992; Liu et al., 1997; Quérat et al., 2000, 2001; Suzuki et al., 1988; Weil et al., 1995; Yoshiura et al., 1997), 4 species of bird (Kikuchi et al., 1998; Koide et al., 1996; Shen and Yu, 2002; GenBank Accession No. BAC07314), 4 species of amphibian (Hayashi et al., 1992; Komoike and Ishii, 2003; Saito et al., 2002; GenBank Accession No. CAC39253), and one species of reptile (Aizawa and Ishii, 2003). These studies have revealed species differences in both nucleotide sequence of FSH $\beta$ cDNAs and the translated protein sequence of FSH $\beta$ molecule. These studies have also demonstrated that the intra-animal class homology of the FSH $\beta$ protein sequence varies greatly between the classes of vertebrate; for example, the homology among 16 species representative of 8 orders of mammals is $84 \%$, while the homology among 24 species representative of 9 orders of fish is only $54 \%$. The findings may imply that the speed of evolution of the FSH $\beta$ molecule differs among different vertebrate classes. Furthermore, the inter-class homology of the FSH $\beta$ protein sequence varies from 40 to $70 \%$. Such high degree of diversity may imply that the FSH $\beta$ molecule has undergone substantial alteration of protein sequence during the course of evolution of vertebrates.

In reptiles, the cDNA encoding $\mathrm{FSH} \beta$ has been reported, recently, for Reeves's turtle (Aizawa and Ishii, 2003). To our knowledge, this is the only species of reptile whose FSH $\beta$ cDNA has been cloned so far. Reptiles occupy a key position in evolutionary history of the vertebrates between the amphibians and the birds and mammals. For better understanding of the phylogenetic diversity and evolution of the pituitary FSH molecule in vertebrates, we have cloned FSH $\beta$ from the Chinese soft-shell turtle, Pelodiscus sinensis (Family of Trionychidae), a reptile that is commercially cultured and easily accessible in Taiwan. The obtained FSH $\beta$ cDNA and the deduced amino acid sequence of the FSH $\beta$ subunit were compared to those of Reeves's turtle (Family of Bataguridae) and those of other vertebrates classes. The in vitro gene expression of FSH $\beta$ mRNA of the Chinese soft-shell turtle pituitary, as challenged by gonadotropin-releasing hormone was also investigated.

\section{Materials and methods}

\subsection{Animal}

Adult male Chinese soft-shell turtles, $P$. sinensis (body weight of 700-1000 g), purchased from a local commercial breeder, were used for this study. All experimental procedures in handing of animals were reviewed and approved by the Laboratory Animal Ethics Committee, Academia Sinica.

\subsection{Oligonucleotide design}

Oligonucleotide primers for the amplification of the Chinese soft-shell turtle FSH $\beta$ cDNA were designed based on the conserved region of chicken (Shen and $\mathrm{Yu}$, 2002) and quail (Kikuchi et al., 1998) FSH $\beta$ subunits. The sense primer and antisense primer used for cloning the Chinese soft-shell turtle FSH $\beta$ are given in Table 1.

Table 1

Primers used for cloning cDNA of the Chinese soft-shell turtle FSH $\beta$ subunit in this study

\begin{tabular}{ll}
\hline Primers & Nucleotide sequence \\
\hline Sense primers & \\
P5'-1 & 5'-TAC AGG ATG AAG ACA ATT AAC-3' \\
P5'-2 & 5'-ATC GCT GTG GAG AAA GAG GAG TGC-3' \\
P5'-3 & 5'-GAT ACT GAC AAC ACC GAC TGC ACT-3' \\
5'-AAP & 5'-GGC CAC GCG TCG ACT AGT ACG GGI \\
& IGG GII GGG IIG-3' \\
Antisense primers & \\
P3'-1 & 5'-AAG GAG CAG TAG CTG GGT-3' \\
P3'-2 & 5'-AAG GAG CAG TAG CTG GGT-3' \\
P3'-3 & 5'-CTC ACA GTG GCA CTC GGT AGC-3' \\
3'-AP & 5'-GGC CAC GCG TCG ACT AGT AC(T) ${ }_{17}$-3' $^{\prime}$ \\
AUAP & 5'-GGC CAC GCG TCG ACT AGT AC-3' \\
$\beta$-Actin & \\
Sense primer & 5'-GGT ATT GTG CTG GAC TCT GGT-3' \\
Antisense & 5'-TTT GGC CAG CCC CAT GGA TGT-3' \\
\multicolumn{1}{c}{ primer } &
\end{tabular}


The primers used for amplification of the $5^{\prime}$ ends of the Chinese soft-shell turtle FSH $\beta$ cDNA were designed from the Chinese soft-shell turtle FSH $\beta$ subclone sequence (Table 1). The $\beta$-actin primers, which served as a reference for the loading amount of total RNA of the tissues, were designed based on the Chinese soft-shell turtle $\beta$-actin subcloned sequence (Chien, J.-T. and $\mathrm{Yu}$, J.Y.-L, unpublished data, Endocrinology Laboratory, Institute of Zoology, Academia Sinica, Taipei).

\section{3. $R N A$ isolation and reverse transcription-polymerase chain reaction}

A total of five experiments were performed for RNA isolation and reverse transcription-polymerase chain reaction (RT-PCR) analysis. Three turtles were used in each experiment. The turtles were sacrificed, pituitary glands were removed and placed into liquid nitrogen. Total pituitary cellular RNA was extracted with total RNA miniprep system kit (Viogene, Sunnyvale, CA). The quality of RNA was measured at $A_{260 \mathrm{~nm}} / A_{280 \mathrm{~nm}}$ (Pharmacia Biotech UV/visible spectrophotometer, Ultrospec 3000 ). Only RNAs with $A_{260 \mathrm{~nm}} / A_{280 \mathrm{~nm}}$ ratios of 1.6 to 2.0 were used for RT-PCR. Reverse transcription was performed using Moloney-murine leukemia virus (MMLV) reverse transcriptase (MMLV-RT) (Stratagene, La Jolla, CA), according to the procedure supplied by the manufacturer. Oligo(dT) primer (100 ng) and total cellular RNA (500 ng) from pituitary glands were heated to $65^{\circ} \mathrm{C}$ for $5 \mathrm{~min}$. Then, $10 \mathrm{U}$ MMLV-RT was added to each reaction and the reactions were incubated for $60 \mathrm{~min}$ at $37^{\circ} \mathrm{C}$. The PCRs were performed under hot-start condition $\left(94^{\circ} \mathrm{C}, 2 \mathrm{~min}\right)$ with $p f u$ Turbo DNA polymerase (Stratagene, La Jolla, CA) for 35 cycles of $94^{\circ} \mathrm{C}(0.5 \mathrm{~min}), 50$ and $72^{\circ} \mathrm{C}(1 \mathrm{~min}$ each), and then 7 min at $72^{\circ} \mathrm{C}$ before holding at $4{ }^{\circ} \mathrm{C}$.

\section{4. $3^{\prime}$ and $5^{\prime}$-rapid amplification of $c D N A$ end $\left(3^{\prime}-, 5^{\prime}-R A C E\right)$}

RACE technique was used to extend the cDNA end of FSH $\beta$ sequence including the $3^{\prime}$ - and 5'-UTR in accordance to the procedures provided by the manufacturer (Life Technologies, Gaithersburg, MD). For 3'RACE, $1 \mu \mathrm{g}$ of pituitary RNA was primed with $3^{\prime}$ adapter primer (3'-AP) and reverse transcribed using MMLV-RT (Super Script II reverse transcriptase, Life Technologies, Gaithersburg, MD) as described above. One microliter (out of $50 \mu \mathrm{l}$ ) of RT product was then amplified by PCR with nest forward primer (P5'-2) of the obtained sequence of the Chinese soft-shell turtle FSH $\beta$ and abridge universal amplification primer (AUAP). For 5'-RACE, the first-strand cDNA was synthesized from $1 \mu \mathrm{g}$ of pituitary RNA using the obtained cDNA sequence (P3'-2) of FSH $\beta$ with MMLV-RT. The original mRNA template was then removed by treat- ment with RNase, and the cDNA was purified by spin cartridge. A homopolymeric tail of dCTP was added to the 3 '-end of the first-strand DNA by terminal deoxynucleotide transferase. PCR amplification was accomplished with $5^{\prime}$ amplified anchor primer (5'-AAP) and a nest sequence primer (P3'-3). The PCR protocols for 3'end were performed under hot-start condition $\left(94^{\circ} \mathrm{C}\right.$, 2 min) with Taq DNA polymerase (Life Technologies, Gaithersburg, MD) for 35 cycles of $94^{\circ} \mathrm{C}(0.5 \mathrm{~min}), 54$ and $72^{\circ} \mathrm{C}\left(1 \mathrm{~min}\right.$ each), and then $7 \mathrm{~min}$ at $72^{\circ} \mathrm{C}$ and nest PCR for 35 cycles of $94^{\circ} \mathrm{C}(0.5 \mathrm{~min}), 50$ and $72^{\circ} \mathrm{C}(1 \mathrm{~min}$ each), and then $7 \mathrm{~min}$ at $72{ }^{\circ} \mathrm{C}$ before holding at $4{ }^{\circ} \mathrm{C}$; and $5^{\prime}$-end were performed under hot-start condition $\left(94^{\circ} \mathrm{C}, 2 \mathrm{~min}\right.$ ) with $\mathrm{Taq}$ DNA polymerase (Life Technologies) for 35 cycles of $94^{\circ} \mathrm{C}(0.5 \mathrm{~min}), 50$ and $72^{\circ} \mathrm{C}$ (1 min each), and then $7 \mathrm{~min}$ at $72^{\circ} \mathrm{C}$ and nest PCR for 35 cycles of $94^{\circ} \mathrm{C}(0.5 \mathrm{~min}), 60$ and $72^{\circ} \mathrm{C}(1 \mathrm{~min}$ each $)$, and then $7 \mathrm{~min}$ at $72^{\circ} \mathrm{C}$ before holding at $4{ }^{\circ} \mathrm{C}$.

\subsection{Nucleotide and amino acid sequence analysis}

Nucleotide sequences of cloned cDNAs or direct PCR cDNA products were commercially determined by fluorescence dye termination reaction (BigDye Terminator Cycle Sequencing Ready Reaction Kit, PerkinElmer, Foster City, CA) and analyzed by automated DNA sequencer (Perkin-Elmer, Foster City, CA). Multiple protein sequence alignment of FSH $\beta$ subunits was performed using ClustalW program (Aiyar, 2000).

\subsection{Tissue specificity of FSH $\beta$ gene expression}

Two experiments were conducted and two turtles were used in each experiment. For the tissue specificity study of FSH $\beta$ gene expression, total RNA was isolated, as described above, from various tissues including pituitary, brain, adipose tissue, thyroid, muscle, liver, heart, and testis. The same amount of total RNAs (100 ng) from each tissue was reverse transcribed to first-strand DNA, and then subjected to PCR amplification (35 cycles) of the entire coding region of the Chinese softshell turtle FSH $\beta$ cDNA by using the primer set $\mathrm{P} 5^{\prime}-1$, P3'-1, and the first strand DNA of each tissue was also subjected to PCR amplification of the Chinese soft-shell turtle $\beta$-actin (35cycles) as a reference for the loading amount of total RNA. PCR products of cDNA were revealed by $2.5 \%$ agarose gel electrophoresis.

\subsection{Regulation of the Chinese soft-shell turtle FSH $\beta$ $m R N A$ expression}

The effects of gonadotropin releasing hormone $(\mathrm{GnRH})$ on FSH $\beta$ mRNA levels of the Chinese softshell turtle pituitary were investigated under in vitro conditions. Mammalian LHRH (acetate salt, pGlu-HisTrp-Ser-Tyr-Gly-Leu-Arg-Pro-Gly- $\mathrm{NH}_{2}$, Sigma-Aldrich, 
USA) was used in this experiment. Pituitaries were removed from adult male turtles and washed immediately in $1 \times$ Hank's buffer (Sigma-Aldrich, USA) twice, then placed in sterile serum-free M199 medium plus antibiotic-antimycotic (Life Technologies, Grand Island, NY) on ice. Extraneous tissue was removed from pituitary. Each pituitary was sliced into 4 pieces, preincubated for $1 \mathrm{~h}$ at $28^{\circ} \mathrm{C}$, and then incubated with $\mathrm{GnRH}$ at doses of $10^{-8}$ and $10^{-6} \mathrm{M}$ in $1.0 \mathrm{ml} \mathrm{M} 199$ medium plus antibiotics-antimycotic under aeration of $95 \% \mathrm{O}_{2}$ and $5 \% \mathrm{CO}_{2}$ for $6 \mathrm{~h}$ at $28^{\circ} \mathrm{C}$. The control groups were without hormonal treatment. At the end of incubation, pituitary tissues were collected for isolation of RNA. The RNA was reverse transcribed to the firststrand DNA as described above. The products were then subjected to fluorescence real-time quantitative PCR analysis to examine the expression level of the Chinese soft-shell turtle FSH $\beta$ mRNA. The FSH $\beta$ cDNA concentration in each sample was first calculated from the standard curve of FSH $\beta$ cDNA and then divided by the concentration of $\beta$-actin to correct the difference of RNA amount in each sample. Fluorescence real-time
PCR was performed to examine the relative mRNA levels using fluorescence dye SYBR Green I for continuous observation of the amplified cDNA level (Morrison et al., 1998). Such assay allows rapid and accurate quantification of initial transcript copy number.

\subsection{Construction of a phylogenetic tree of vertebrate FSH $\beta$ subunits}

A phylogenetic tree of selected vertebrate FSH $\beta$ s was constructed based on the aligned amino acid sequences, and analysed by the neighbor-joining method (Molecular Evolutionary Genetic Analysis, MEGA, Ver 2.1). For deriving the confidence value for this analysis, bootstrap trials were replicated 1000 times. GenBank accession numbers and references of FSH $\beta$ sequences analyzed in this study are shown in Table 2.

\subsection{Statistical analysis}

The data obtained from fluorescence real-time PCR analysis for the regulation of FSH $\beta$ mRNA expression

Table 2

Species and references of FSH $\beta$ s used for sequence comparison in this study

\begin{tabular}{|c|c|c|c|c|c|}
\hline Animal class/species & Scientific name & Order & Family & GenBank Accession No. & Reference \\
\hline \multicolumn{6}{|l|}{ Reptiles } \\
\hline Chinese soft-shell turtle & P. sinensis & Testudinoidea & Trionychidae & & This study \\
\hline Reeves's turtle & Chinemys reevesii & Testudinoidea & Bataguridae & BAB92948 & Aizawa and Ishii (2003) \\
\hline \multicolumn{6}{|l|}{ Birds } \\
\hline Chicken & Gallus domesticus & Galliformes & Phasianidae & NP989588 & Shen and Yu (2002) \\
\hline Quail & Coturnix japonica & Galliformes & Phasianidae & BAC01164 & Kikuchi et al. (1998) \\
\hline Crested ibis & Nipponia nippon & Ciconiiformes & Threskiornithidae & BAC07314 & - \\
\hline Ostrich & Struthio camelus & Struthioniformes & Struthionidae & P80663 & Koide et al. (1996) \\
\hline \multicolumn{6}{|l|}{ Mammals } \\
\hline Ovine & Ovis aries & Cetartiodactyla & Bovidae & P01227 & Sairam et al. (1981) \\
\hline Porcine & Sus scrofa & Cetartiodactyla & Suidae & AAA31039 & Kato (1988) \\
\hline Equine & Equus caballus & Perissodactyla & Equidae & & Fujiki et al. (1978) \\
\hline Human & Homo sapiens & Primates & Hominidae & NP000501 & Jameson et al. (1988) \\
\hline Rat & Rattus norvegicus & Rodentia & Muridae & BAA00455 & Maurer (1987) \\
\hline Opossum & Trichosurus vulpecula & Didelphimorphia & Phalangeridae & AAC71065 & Lawrence et al. (1997) \\
\hline \multicolumn{6}{|l|}{ Amphibians } \\
\hline Newt & Cynops pyrrhogaster & Caudata & Salamandridae & ВАВ92958 & Saito et al. (2002) \\
\hline Bullfrog & Rana catesbeiana & Anura & Ranidae & Q9PS36 & Hayashi et al. (1992) \\
\hline Marsh frog & Rana ridibunda & Anura & Ranidae & CAC39253 & - \\
\hline Japanese toad & Bufo japonicus & Anura & Bufonidae & BAB93559 & Komoike and Ishii (2003) \\
\hline \multicolumn{6}{|l|}{ Chondrichthyan } \\
\hline Dogfish & Squalus acanthias & Carcharhiniformes & Squalidae & AJ310344 & Quérat et al. (2001) \\
\hline \multicolumn{6}{|l|}{ Chondrostean } \\
\hline Sturgeon & Acipenser baerii & Acipenseriformes & Acipenseridae & CAB93504 & Quérat et al. (2000) \\
\hline \multicolumn{6}{|l|}{ Teleosts } \\
\hline Lungfish & Neoceratodus forsteri & Ceratodontiformes & Ceratodontidae & CAE17337 & Quérat et al. (2004) \\
\hline European eel & Anguilla anguilla & Anguilliformes & Anguillidae & AAN64352 & Degani et al. (2003) \\
\hline Goldfish & Carassius auratus & Cypriniformes & Cyprinidae & BAA 13530 & Yoshiura et al. (1997) \\
\hline Rainbow trout & Oncorhynchus mykiss & Salmoniformes & Salmonidae & BAB17686 & - \\
\hline Chum salmon & Oncorhynchus keta & Salmoniformes & Salmonidae & AAA49408 & Itoh et al. (1988) \\
\hline Striped bass & Morone saxatilis & Perciformes & Moronidae & & Hassin et al. (1995) \\
\hline Snakehead fish & Channa maculata & Perciformes & Retroviridae & AY447038 & - \\
\hline
\end{tabular}

"_." The sequences were submitted to GenBank only. 
by $\mathrm{GnRH}$ were subjected to one way analysis of variance (one-way ANOVA). Differences between doses of the GnRH treated group and the controls (without hormonal treatment) were tested by Newman-Keuls' test and considered significant at $P \leqslant 0.05$.

\section{Results}

\subsection{Cloning and sequence analysis of FSH $\beta$ cDNA for the} Chinese soft-shell turtle pituitary

A PCR product containing $396 \mathrm{bp}$ was obtained and appeared as a single band on a $2.5 \%$ agarose gel; it was identified to encode the Chinese soft-shell turtle FSH $\beta$ subunit precursor molecule from its nucleotide sequence. To determine the remaining $3^{\prime}$ and $5^{\prime}$ portions of the Chinese soft-shell turtle FSH $\beta$ cDNA sequence, $5^{\prime}$ and $3^{\prime}$ rapid amplification of cDNA end (RACE) were performed. The cloned Chinese soft-shell turtle FSH $\beta$
cDNA contained 602-bp nucleotides, including 34-bp nucleotides of $5^{\prime}$ untranslated region (UTR), 396-bp of the open reading frame, and 206-bp of 3' UTR (Fig. 1). No polyadenylation site was identified in the FSH $\beta$ cDNA. The precursor protein of the Chinese soft-shell turtle FSH $\beta$ subunit contained a putative signal peptide of 20 amino acids and a mature protein of 111 amino acids (Fig. 1). The mature protein of the Chinese softshell turtle FSH $\beta$ is compared to FSH $\beta$ s of Reeves's turtle, avian, mammalian, amphibian, and fish species (Fig. 2). As indicated, 12 cysteine residues of the Chinese softshell turtle FSH $\beta$ are conserved as for other tetrapod vertebrates at positions $1,15,18,26,30,49,64,80,82,85$, 92, and 102. One asparagine-linked glycosylation site, located at position 5 between the 1st cysteine and the 2nd cysteine, is conserved in the Chinese soft-shell turtle as in other vertebrates from fish through mammals, while the other asparagine-linked glycosylation site, located at position 22 between the 3 rd cysteine and the 4th cysteine is also conserved in the Chinese soft-shell

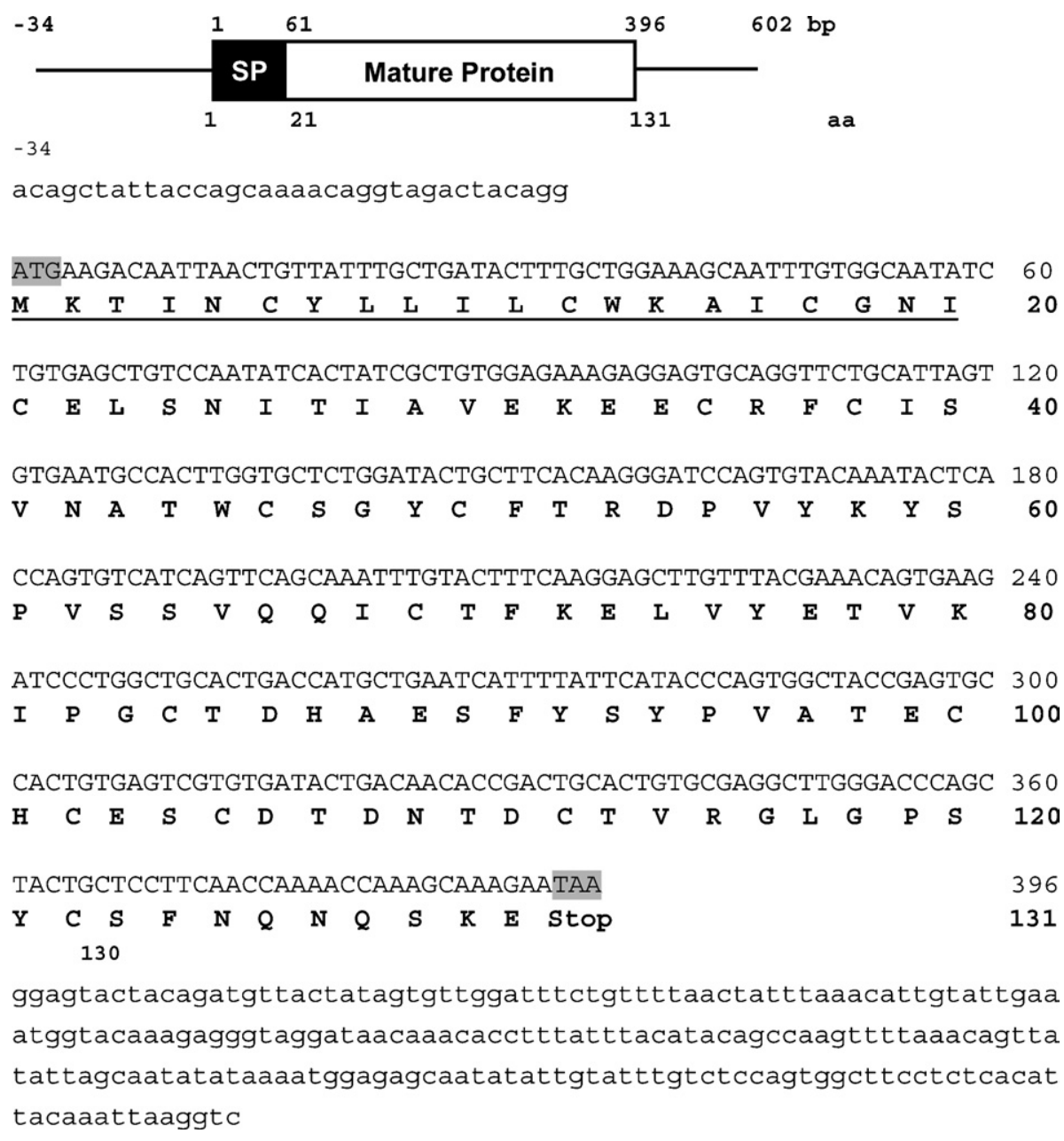

Fig. 1. The nucleotide sequence of the Chinese soft-shell turtle FSH $\beta$ cDNA includes $34 \mathrm{bp}$ of $5^{\prime}$-untranslated region, $396 \mathrm{bp}$ of coding region, and $206 \mathrm{bp}$ of nucleotide sequence of $3^{\prime}$-untranslated region. The predicted open reading frame encodes a precursor protein of 131 amino acid with a signal peptide (SP) of 20 amino acids and a mature protein of 111 amino acids as shown under the nucleotide sequence. The start codon (ATG) and stop codon (TAA) are shown as boxed and shaded. The signal peptide (residues 1-20) is shown by underline. 


Chinese soft-
$\quad$ Shell turtle
Reeves's turtle
Chicken
Quail
Crested Ibis
Ostrich
Ovine
Porcine
Equine
Human
Rat
Opossum
Newt*
Bullfrog
Marsh frog
Japanese toad
Dogfish
Sturgeon
Lungfish
European eel
Goldfish
Rainbow trout
Chum salmon
Striped bass
Snakehead fish

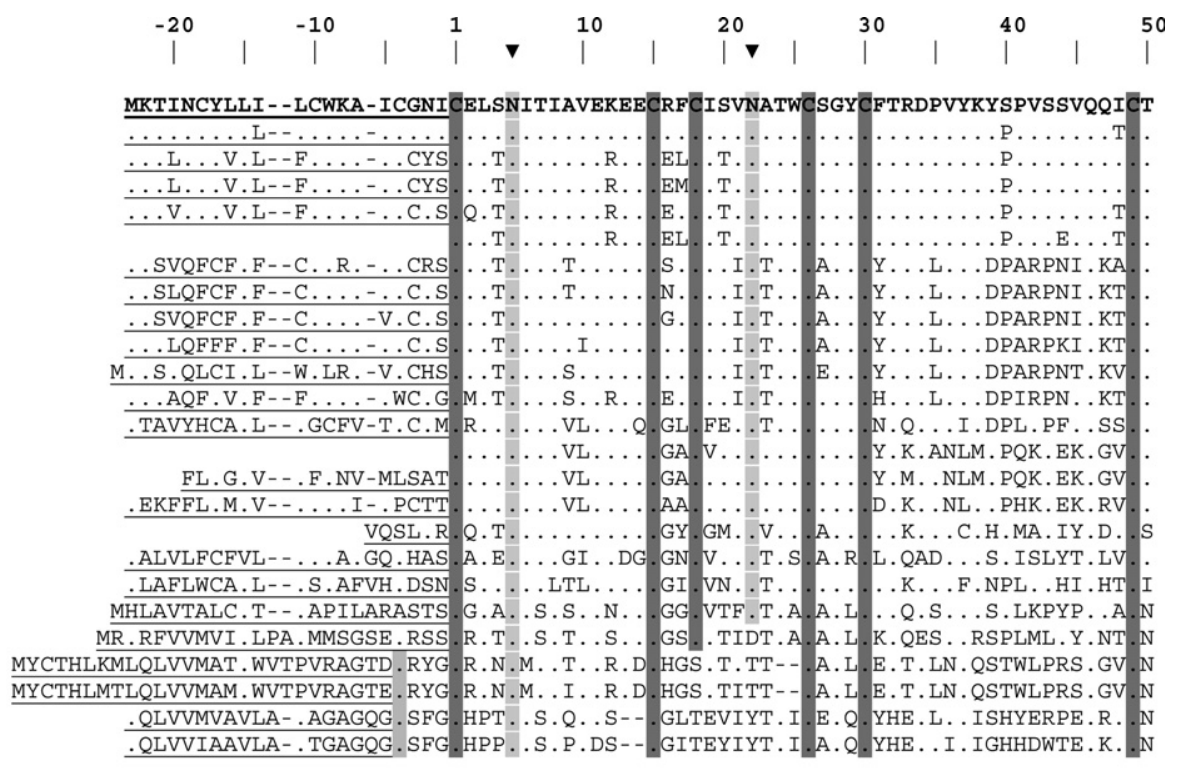

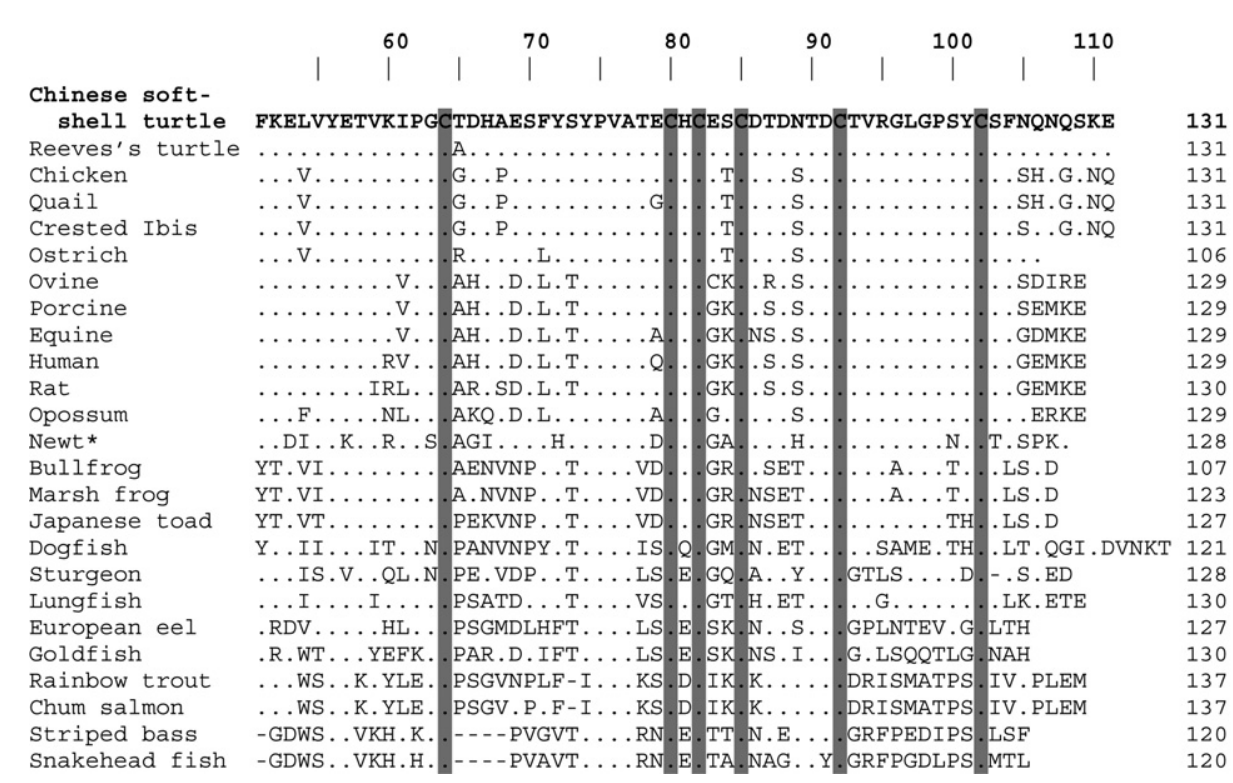

Fig. 2. Multiple sequence alignments of FSH $\beta$ subunits. The deduced amino acid sequence of the Chinese soft-shell turtle FSH $\beta$ cDNA are aligned with FSH $\beta$ subunit protein sequences from selected species of different vertebrate groups (see Table 2 for references). For convenience, all FSH $\beta s$ are numbered in accordance with the Chinese soft-shell turtle FSH $\beta$ from the putative N-terminus. Residues identical to the Chinese soft-shell turtle FSH $\beta$ are presented as dots ( $\cdot)$. Hyphens (-) have been inserted to show deletion of amino acids in order to obtain maximum homology. Twelve cysteine residues, forming six disulfide linkages, are shaded. Two putative N-linked glycosylation sites of tetrapods are denoted by $\boldsymbol{\nabla}$ and lightly shadowed in gray. The numericals at the right column are the total numbers of amino acids of FSH $\beta$ precursor proteins of the selected vertebrate species. The signal peptides are underlined. * For alignment of maximal homology, the extra Gly residue originally appeared immediately after the 7th Cys was deleted (Saito et al., 2002).

turtle as in other tetrapod vertebrates and certain more primitive fish.

\subsection{Tissue specificity of FSH $\beta$ gene expression}

To examine the tissue specificity of $\mathrm{FSH} \beta$ gene expression, the entire open reading frame of the Chinese soft-shell turtle FSH $\beta$ cDNA was amplified by RT-PCR of total RNA from various tissues. As shown in Fig. 3, FSH $\beta$ mRNA was only expressed in the pituitary, but not in brain, adipose tissue, thyroid, muscle, liver, heart, and testis. The nucleotide sequence of FSH $\beta$ cDNA cloned from pituitary is identical to the $\mathrm{FSH} \beta$ nucleotide sequence described above.

\subsection{Regulation of the Chinese soft-shell turtle FSH $\beta$ $m R N A$ expression by $G n R H$}

To study the regulation of FSH $\beta$ mRNA expression by $\mathrm{GnRH}$ in the Chinese soft-shell turtle, pituitary 


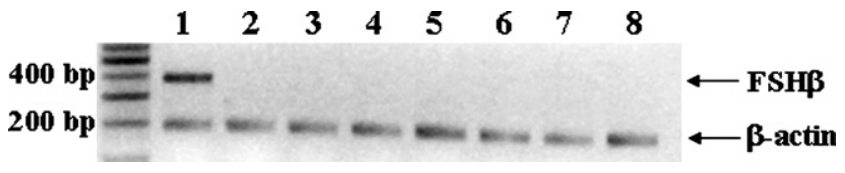

Fig. 3. The tissue specificity of FSH $\beta$ mRNA expression analyzed by RT-PCR $100 \mathrm{ng}$ of total RNA each from pituitary (lane 1), brain (lane 2), adipose tissue (lane 3), testis (lane 4), heart (lane 5), thyroid (lane 6), liver (lane 7), and muscle (lane 8) was subjected to RT-PCR for FSH $\beta$ cDNA amplification and also $\beta$-actin amplification (35 cycles) which served as a reference of the loading amount of total RNA for each tissue. PCR products of cDNAs were revealed by $2.5 \%$ agarose gel electrophoresis.
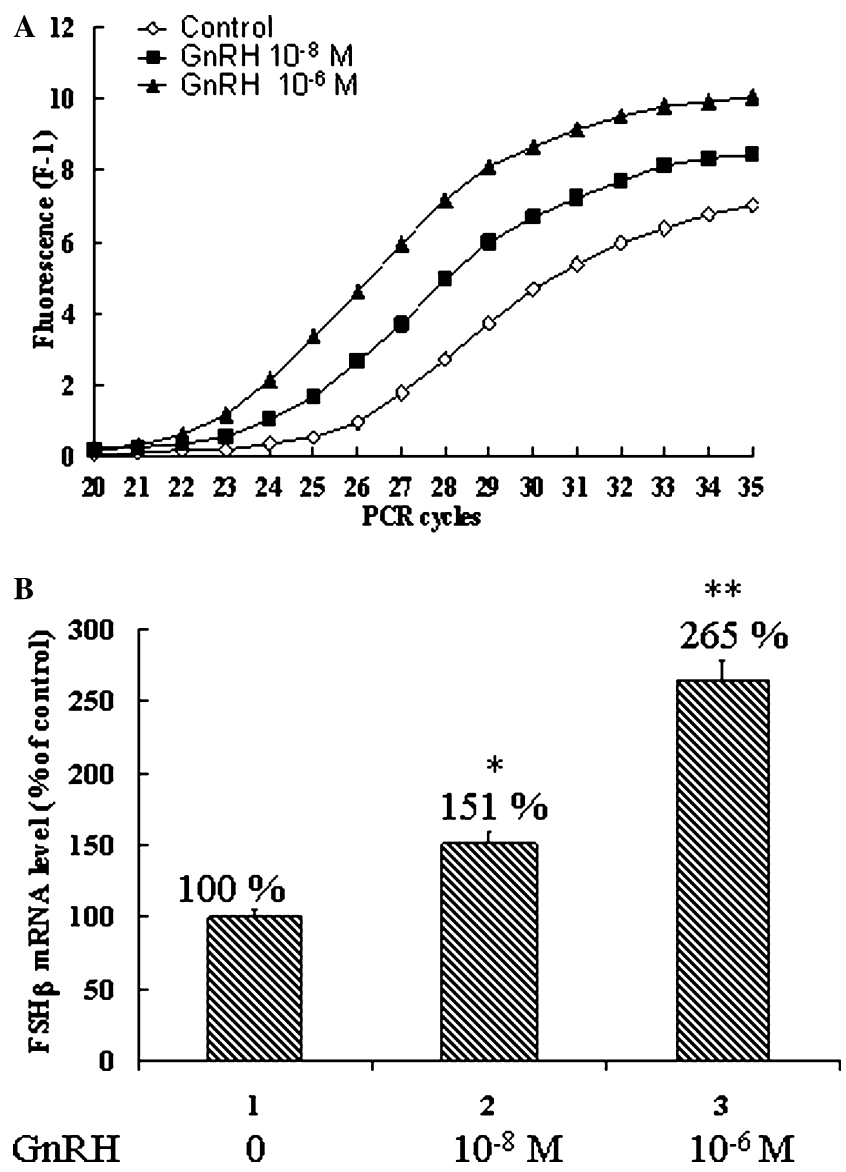

Fig. 4. The effects of GnRH treatment on the gene expression of the Chinese soft-shell turtle FSH $\beta$ mRNA. (A) A representative fluorescence real-time PCR of FSH $\beta$ cDNA for cultured Chinese soft-shell turtle pituitary tissues treated with medium, $10^{-8} \mathrm{M}$ GnRH, and $10^{-6} \mathrm{M}$ GnRH, respectively. (B) The increased percentage of $\mathrm{FSH} \beta$ mRNA level of the Chinese soft-shell turtle pituitary cultured with two doses of GnRH. Values represent means \pm SD of three separate experiments $\left({ }^{*} P<0.05,{ }^{* *} P<0.01\right)$, see Section 2 for further details.

fragments were cultured and treated for $6 \mathrm{~h}$ with different doses of GnRH. As shown in Fig. 4, the FSH $\beta$ mRNA levels of the Chinese soft-shell turtle pituitaries treated with $\mathrm{GnRH}$ at doses of $10^{-8}$ and $10^{-6} \mathrm{M}$ as analyzed by fluorescence real-time PCR were 151 and $265 \%$, respectively, in comparison to the controls $(100 \%)$.

\section{Discussion}

The cloned Chinese soft-shell turtle FSH $\beta$ cDNA contains 396-bp nucleotide of the open-reading frame (Fig. 1). It encodes a putative precursor protein molecule of 131 amino acids with a signal peptide of 20 amino acids and a mature protein of 111 amino acids. The deduced amino acid sequence of the Chinese soft-shell turtle FSH $\beta$ mature protein shares identities of $94 \%$ with Reeve turtle, $83-89 \%$ with birds, $61-70 \%$ with mammals, $63-66 \%$ with amphibians, and $40-58 \%$ with fish (Table 3 ). The present study demonstrated that the number and position of 12 cysteine residues and two asparagine linked glycosylation sites have been conserved in the Chinese soft-shell turtle FSH $\beta$ and all other tetrapod vertebrates so far studied (Fig. 2).

As indicated in Fig 2, the positions of the 12 cysteine residues in FSH $\beta$ are all conserved in amphibians, reptiles, birds, and mammals so far studied. In certain fish (Elasmobranch: dogfish; Chondrostean: sturgeon; and less derived teleosts: goldfish, salmon, and rainbow trout) the same 12 cysteine residues are also conserved. However, in more highly derived teleosts such as Perciformes: stripe bass and snakehead fish, the position of the 3 rd cysteine residue is shifted to the $\mathrm{N}$-terminus. By contrast, the positions of the 12 cysteine residues are all

Table 3

Comparison of the percentage identity of mature protein of pituitary FSH $\beta$ subunit nucleotide and amino acid sequences between the Chinese soft-shell turtle and other selected vertebrates

\begin{tabular}{lll}
\hline Species & $\begin{array}{l}\text { Nucleotide } \\
\text { (Identity, \%) }\end{array}$ & $\begin{array}{l}\text { Amino acid } \\
\text { (Identity, \%) }\end{array}$ \\
\hline Chinese soft-shell turtle & 100 & 100 \\
Reeves's turtle & 93 & 97 \\
Chicken & 82 & 86 \\
Quail & 78 & 85 \\
Crested ibis & 79 & 86 \\
Ostrich & $(\mathrm{a})$ & 84 \\
Ovine & 69 & 68 \\
Porcine & 73 & 69 \\
Equine & $(\mathrm{a})$ & 68 \\
Human & 73 & 68 \\
Rat & 70 & 68 \\
Opossum & 71 & 67 \\
Newt & 68 & 63 \\
Bullfrog & 61 & 60 \\
Marsh frog & 61 & 61 \\
Japanese toad & 61 & 61 \\
Lungfish & 66 & 62 \\
Dogfish & 60 & 52 \\
Sturgeon & 55 & 50 \\
European eel & 50 & 44 \\
Goldfish & 47 & 40 \\
Rainbow trout & 48 & 37 \\
Chum salmon & 47 & 38 \\
Striped bass & 40 & 32 \\
Snakehead fish & 42 & 29 \\
\hline
\end{tabular}

The references for $\mathrm{FSH} \beta \mathrm{s}$ of vertebrates used for comparisons are indicated in Table 2. (a) cDNAs were not cloned; their amino acid residues were obtained from the chemical analysis of the isolated FSH $\beta$. 


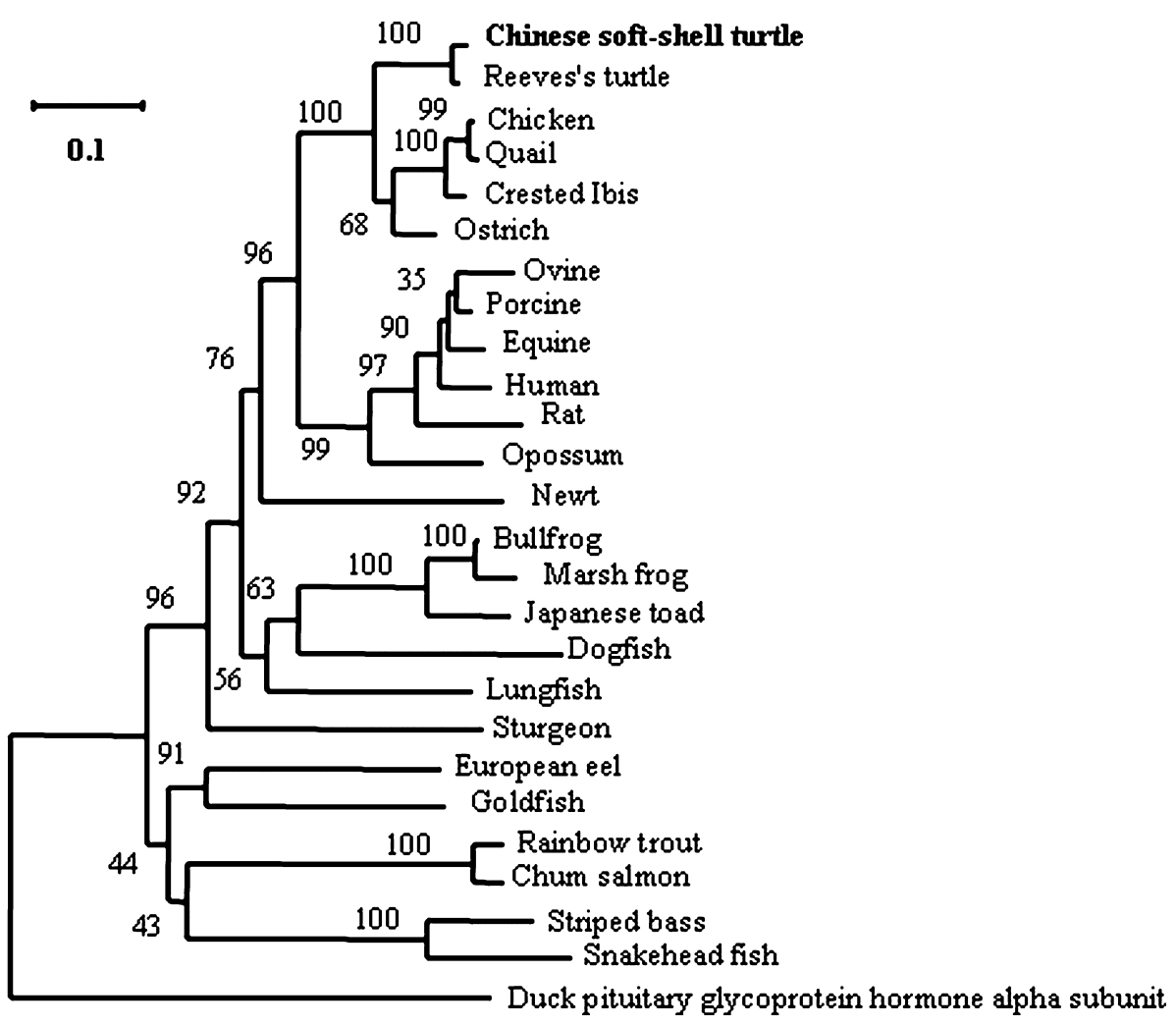

Fig. 5. A phylogenetic tree of vertebrate FSH $\beta$ subunit protein. Data were calculated with Blosum-62-amino-acid substitution matrix and constructed by neighbor-joining method from the mature protein. The duck pituitary glycoprotein hormone $\alpha$ subunit (Hsieh et al., 2001) was used as an outgroup to root the tree. Bootstrap values (100 of 1000 replicant) are indicated. The source and references of the selected FSH $\beta$ data are indicated in Table 2.

conserved in LH $\beta$ and TSH $\beta$ in both fish and tetrapods so far studied (Hsieh et al., 2000; Han et al., 2004; Komoike and Ishii, 2003; Pierce and Parsons, 1981; Quérat et al., 2001). Two conserved asparagine (Asn) Nlinked glycosylation sites (Asn-X-Ser/Thr) of FSH $\beta$ s observed in mammals, birds, amphibians and certain fish are also found in the Chinese soft-shell turtle $\mathrm{FSH} \beta$ subunit $\left(\mathrm{Asn}_{5}\right.$-Ile-Thr and $\mathrm{Asn}_{22}$-Ala-Thr). However, there is only one $\mathrm{N}$-linked glycosylation site present in certain other fish. A phylogenetic tree of vertebrate FSH $\beta$ s, including a reptile for the first time, is presented based on the homology of their amino acid sequences (Fig. 5). The homologies between amniote vertebrate (reptiles, birds, and mammals) FSH $\beta$ s are much greater than between LH $\beta$ s. This fact indicates that FSH $\beta$ subunit is more conserved than LH $\beta$ subunit during evolution of amniote vertebrates. These observations agree well with the LH and FSH bioassay results from our laboratory: LHs from various tetrapod species show remarkable variation of potency $(>10,000$-fold) in the LH bioassays employing the stimulation of testicular androgen in vitro (Yu et al., 1995, 1996; Yu and Wang, 1987); by contrast, FSHs from various tetrapod species show less variation of potencies ( $\sim 1000$-fold) in a FSH bioassay stimulating $17 \beta$-estradiol formation in immature rat Sertoli cells in vitro (Yu et al., 1996).
In studies of the GTH-receptor interaction, Moyle et al. (1994) illustrated that hCG/ hFSH chimeras containing human FSH $\beta$ subunit residues between cysteines 11 and 12 were able to bind FSH receptors with high affinity and elicited signal transduction. They also found that the chimeras containing human FSH $\beta$ subunit residues between cysteines 10 and 11 had low LH activity. It has been shown that mammalian FSHs, but not LHs, bind to the FSH receptor on Sertoli cells isolated from immature male rats, activating aromatase, which is responsible for estrogen formation from exogenous androgen (Dorrington and Armstrong, 1975). Such a system has been employed to assay the bioactivity of mammalian FSHs in vitro (Padmanabhan et al., 1987; Shen and Yu, 1991; Van Damme et al., 1979). We further demonstrated that both FSHs and LHs of reptiles (snapping turtle) and birds (chicken, ostrich, and turkey) can stimulate estradiol formation in such an in vitro FSH bioassay ( $\mathrm{Yu}$ et al., 1996). As indicated in Fig. 6, the amino acids between cysteines 11 and 12 of FSH $\beta$ subunits in reptiles, birds, and mammals are identical. It is interesting to note that the corresponding region of $\mathrm{LH} \beta$ subunits in reptiles and birds is highly similar to that of FSH $\beta$ subunits; however, in mammals, such a region of LH $\beta$ subunits differs considerably from that of FSH $\beta$ subunits. Presumably, the reptilian and avian LHs are 


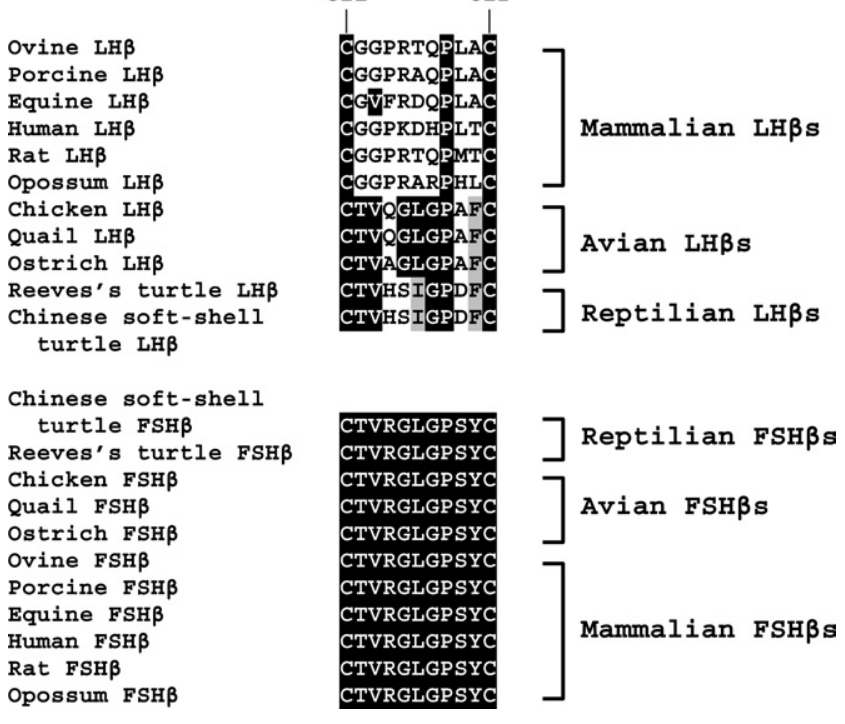

Fig. 6. Comparison of amino acid sequence in the region between cysteines 11 and 12 of mammalian, reptilian, and avian FSH $\beta$ s and LH $\beta$ s. Reptilian and avian, but not mammalian, LH $\beta$ s resemble their respective FSH $\beta$ s in this 9-member amino acid. Identical amino acids are shown in white letters shaded in black. Isoleucine (I) and phenylalanin (F) are physicochemically similar to leucine (L) and tyrosin (Y), respectively, are shaded in gray. The FSH $\beta$ s compared are listed in Table 1. The LH $\beta$ s compared are: Reeves's turtle LH $\beta$ (Aizawa and Ishii, 2003), Chinese soft-shell turtle LH $\beta$ (deduced amino acids from LH $\beta$ cDNA from Chien, J.T. and Yu, J.Y.L. Endocrinology Laboratory, Institute of Zoology, Academia Sinica, Taipei, unpublished data), chicken (Noce et al., 1989), quail (Ando and Ishii, 1994), ostrich (Koide et al., 1996), ovine (d'Angelo-Bernard et al., 1990), porcine (GenBank Accession No. AAP92114), equine (Sugino et al., 1987), human (Virgin et al., 1985), and rat (Ezashi et al., 1990).

recognized as FSHs by the FSH receptor of Sertoli cells isolated from immature rat testis. These facts may explain why both FSH and LH of reptiles and birds are active in FSH bioassay employing immature rat Sertoli cells (Yu et al., 1996).

The formation and secretion of FSH are mainly regulated by hypothalamic and gonadal factors, such as $\mathrm{GnRH}$, activin, inhibin, and gonadal steroid hormone. Hypothalamic GnRH acts directly on synthesis and release of pituitary LH and FSH in mammals (Schally et al., 1971, 1972; Yu et al., 1979). In reptiles, it has been demonstrated that chicken-I, chicken II, and mammalian GnRH stimulated in vitro the release of $\mathrm{LH}$ in three species of turtle, and the potencies of these GnRHs in the stimulation of LH release were similar (Licht and Porter, 1985a,b; Licht et al., 1987; Tsai and Licht, 1993). The stimulatory action of GnRH on pituitary FSH release has not been reported previously in reptiles. GnRH enhances the mRNA levels of FSH $\beta$ subunits in mammals (Attardi and Winters, 1993; Dalkin et al., 1999), bird (Shen and Yu, 2002), and fish (Dickey and Swanson, 2000; Gur et al., 2002; Kandel-Kfir et al., 2002). The present study, has demonstrated that hypophysial FSH $\beta$ mRNA levels of the Chinese soft-shell turtle pituitary are also promoted by GnRH under static culture conditions (Fig. 4). This is the first demonstration in reptiles that GnRH upregulates FSH $\beta$ mRNA expression. Our findings together with the observations reported by others on mammals, birds, and fish support the proposal that hypothalamic GnRH up-regulation of FSH $\beta$ mRNA gene is common to all vertebrates.

\section{Acknowledgments}

This study was supported by grants from National Science Council and Academia Sinica, Taipei, Taiwan, Republic of China.

\section{References}

Aiyar, A., 2000. The use of CLUSTAL W and CLUSTAL $\mathrm{X}$ for multiple sequence alignment. Methods Mol. Biol. 132, 221-241.

Aizawa, Y., Ishii, S., 2003. Cloning of the cDNAs encoding the beta subunit precursor molecules of pituitary glycoprotein hormones in the Reeves's turtle (Geoclemys reevesii) and Japanese grass lizard (Takydromus tachydromoides). Gen. Comp. Endocrinol. 132, 465473.

Ando, H., Ishii, S., 1994. Molecular cloning of complementary deoxyribonucleic acids for the pituitary glycoprotein hormone alpha-subunit and luteinizing hormone beta-subunit precursor molecules of Japanese quail (Coturnix coturnix japonica). Gen. Comp. Endocrinol. 93, 357-368.

d'Angelo-Bernard, G., Moumni, M., Jutisz, M., Counis, R., 1990. Cloning and sequence analysis of the cDNA for the precursor of the beta subunit of ovine luteinizing hormone. Nucleic Acids Res. 18, 2175.

Attardi, B., Winters, S.J., 1993. Decay of follicle-stimulating hormonebeta messenger RNA in the presence of transcriptional inhibitors and/or inhibin, activin, or follistatin. Mol. Endocrinol. 7, 668-680.

Belov, K., Harrison, G.A., Cooper, D.W., 1998. Cloning of the red kangaroo (Macropus rufus) follicle stimulating hormone beta subunit. Reprod. Fertil. Dev. 10, 289-291.

Dalkin, A.C., Haisenleder, D.J., Gilrain, J.T., Aylor, K., Yasin, M., Marshall, J.C., 1999. Gonadotropin-releasing hormone regulation of gonadotropin subunit gene expression in female rats: actions on follicle-stimulating hormone beta messenger ribonucleic acid (mRNA) involve differential expression of pituitary activin $(\beta-B)$ and follistatin mRNAs. Endocrinology 140, 903-908.

Degani, G., Goldberg, D., Tzchori, I., Hurvitz, A., Yom Din, S., Jackson, K., 2003. Cloning of European eel (Anguilla anguilla) FSHbeta subunit, and expression of FSH-beta and LH-beta in males and females after sex determination. Comp. Biochem. Physiol. B 136, 283-293.

Dickey, J.T., Swanson, P., 2000. Effects of salmon gonadotropin-releasing hormone on follicle stimulating hormone secretion and subunit gene expression in coho salmon (Oncorhynchus kisutch). Gen. Comp. Endocrinol. 118, 436-449.

Dorrington, J.H., Armstrong, D.T., 1975. Follicle-stimulating hormone stimulates estradiol-17 $\beta$ synthesis in cultured Sertoli cells. Proc. Natl. Acad. Sci. USA 72, 2677-2681.

Ezashi, T., Hirai, T., Kato, T., Wakabayashi, K., Kato, Y., 1990. The gene for the beta subunit of porcine LH: clusters of GC boxes and CACCC elements. J. Mol. Endocrinol. 5, 137-146.

Fujiki, Y., Rathnam, P., Saxena, B.B., 1978. Amino acid sequence of the beta-subunit of the follicle-stimulating hormone from equine pituitary glands. J. Biol. Chem. 253, 5363-5368. 
Fox, K.M., Dias, J.A., Van Roey, P., 2001. Three-dimensional structure of human follicle-stimulating hormone. Mol. Endocrinol. 15, 378389.

Gur, G., Bonfil, D., Safarian, H., Naor, Z., Yaron, Z., 2002. GnRH signaling pathways regulate differentially the tilapia gonadotropin subunit genes. Mol. Cell. Endocrinol. 189, 125-134.

Han, Y.S., Liao, I.C., Tzeng, W.N., Yu, J.Y.L., 2004. Cloning of the cDNA for thyroid stimulating hormone beta subunit and changes in activity of the pituitary-thyroid axis during silvering of the Japanese eel, Anguilla japonica. J. Mol. Endocrinol. 32, 179-194.

Hayashi, T., Hanaoka, Y., Hayashi, H., 1992. The complete amino acid sequence of the follitropin beta-subunit of the bullfrog, Rana catesbeiana. Gen. Comp. Endocrinol. 88, 144-150.

Hassin, S., Elizur, A., Zohar, Y., 1995. Molecular cloning and sequence analysis of striped bass (Morone saxatilis) gonadotrophin-I and -II subunits. J. Mol. Endocrinol. 15, 23-35.

Hsieh, Y.L., Chatterjee, A., Lee, G., Yu, J.Y.L., 2000. Molecular cloning and sequence analysis of the cDNA for thyroid-stimulating hormone $\beta$ subunit of Muscovy duck. Gen. Comp. Endocrinol. 120, 336-344.

Hsieh, Y.L., Chatterjee, A., Chien, J.T., Yu, J.Y.L., 2001. Molecular cloning of the cDNAs for pituitary glycoprotein hormone alpha subunits of two species of duck and their gene regulation. J. Mol. Endocrinol. 27, 339-347.

Itoh, H., Suzuki, K., Kawauchi, H., 1988. The complete amino acid sequences of beta-subunits of two distinct chum salmon GTHs. Gen. Comp. Endocrinol. 71, 438-451.

Jackson, K., Goldberg, D., Ofir, M., Abraham, M., Degani, G., 1999. Blue gourami (Trichogaster trichopterus) gonadotropic beta subunits (I and II) cDNA sequences and expression during oogenesis. J. Mol. Endocrinol. 23, 177-187.

Jameson, J.L., Becker, C.B., Lindell, C.M., Habener, J.F., 1988. Human follicle-stimulating hormone beta-subunit gene encodes multiple messenger ribonucleic acids. Mol. Endocrinol. 2, 806-815.

Kajimura, S., Yoshiura, Y., Suzuki, M., Aida, K., 2001. cDNA cloning of two gonadotropin beta subunits (GTH-Ibeta and -IIbeta) and their expression profiles during gametogenesis in the Japanese flounder (Paralichthys olivaceus). Gen. Comp. Endocrinol. 122, $117-129$.

Kandel-Kfir, M., Gur, G., Melamed, P., Zilberstein, Y., Cohen, Y., Zmora, N., Kobayashi, M., Elizur, A., Yaron, Z., 2002. Gonadotropin response to GnRH during sexual ontogeny in the common carp, Cyprinus carpio. Comp. Biochem. Physiol. B 132, 17-26.

Kato, Y., 1988. Cloning and DNA sequence analysis of the cDNA for the precursor of porcine follicle stimulating hormone (FSH) beta subunit. Mol. Cell. Endocrinol. 55, 107-112.

Kato, Y., Gen, K., Maruyama, O., Tomizawa, K., Kato, T., 1993. Molecular cloning of cDNAs encoding two gonadotrophin beta subunits (GTH-I beta and -II beta) from the masu salmon, Oncorhynchus masou: rapid divergence of the GTH-I beta gene. J. Mol. Endocrinol. 11, 275-282.

Kikuchi, M., Kobayashi, M., Ito, T., Kato, Y., Ishii, S., 1998. Cloning of complementary deoxyribonucleic acid for the follicle-stimulating hormone-beta subunit in the Japanese quail. Gen. Comp. Endocrinol. 111, 376-385.

Koide, Y., Papkoff, H., Kawauchi, H., 1996. Complete amino acid sequences of follitropin and lutropin in the ostrich, Struthio camelus. Eur. J. Biochem. 240, 262-267.

Komoike, Y., Ishii, S., 2003. Cloning of cDNAs encoding the three pituitary glycoprotein hormone beta subunit precursor molecules in the Japanese toad, Bufo japonicus. Gen. Comp. Endocrinol. 132, 333-347.

Koura, M., Handa, H., Noguchi, Y., Takano, K., Yamamoto, Y., Matsuda, J., Suzuki, O., 2004. Sequence analysis of cDNA encoding follicle-stimulating hormone and luteinizing hormone beta-subunits in the Mongolian gerbil (Meriones unguiculatus). Gen. Comp. Endocrinol. 136, 406-410.
Kumar, T.R., Kelly, M., Mortrud, M., Low, M.J., Matzuk, M.M., 1995. Cloning of the mouse gonadotropin beta-subunit-encoding genes, I. Structure of the follicle-stimulating hormone beta-subunitencoding gene. Gene 166, 333-334.

Lapthorn, A.J., Harris, D.C., Littlejohn, A., Lustbader, J.W., Canfield, R.E., Machin, K.J., Morgan, F.J., Isaacs, N.W., 1994. Crystal structure of human chorionic gonadotropin. Nature 369, 455-461.

Lawrence, S.B., Vanmontfort, D.M., Tisdall, D.J., McNatty, K.P., Fidler, A.E., 1997. The follicle-stimulating hormone beta-subunit gene of the common brushtail possum (Trichosurus vulpecula): analysis of cDNA sequence and expression. Reprod. Fertil. Dev. 9, 795-801.

Liao, M.J., Zhu, M.Y., Zhang, Z.H., Zhang, A.J., Li, G.H., Sheng, F.J., 2003. Cloning and sequence analysis of FSH and LH in the giant panda (Ailuropoda melanoleuca). Anim. Reprod. Sci. 77, 107-116.

Licht, P., Porter, D.A., 1985a. LH secretion in response to gonadotropin releasing hormone $(\mathrm{GnRH})$ by superfused pituitaries from two species of turtles. Gen. Comp. Endocrinol. 59, 442-448.

Licht, P., Porter, D.A., 1985b. In vivo and in vitro responses to gonadotropin releasing hormone in the turtle, Chrysemys picta, in relation to sex and reproductive stage. Gen. Comp. Endocrinol. 60, 75-85.

Licht, P., Porter, D., Millar, R.P., 1987. Specificity of amphibian and reptilian pituitaries for various forms of gonadotropin-releasing hormones in vitro. Gen. Comp. Endocrinol. 66, 248-255.

Lin, Y.W., Rupnow, B.A., Price, D.A., Greenberg, R.M., Wallace, R.A., 1992. Fundulus heteroclitus gonadotropins. 3. Cloning and sequencing of gonadotropic hormone (GTH) I and II beta-subunits using the polymerase chain reaction. Mol. Cell. Endocrinol. 85, 127-139.

Liu, Z., Li, P., Argue, B.J., Dunham, R.A., 1997. Gonadotropin alphasubunit glycoprotein from channel catfish (Ictalurus punctatus) and its expression during hormone-induced ovulation. Mol. Mar. Biol. Biotechnol. 6, 217-227.

Maurer, R.A., 1987. Molecular cloning and nucleotide sequence analysis of complementary deoxyribonucleic acid for the beta-subunit of rat follicle stimulating hormone. Mol. Endocrinol. 1, 717-723.

Morrison, T.B., Weis, J.J., Wittwer, C.T., 1998. Quantification of low copy transcripts by continuous SYBR Green 1 monitoring during amplification. BioTechniques 24, 954-962.

Moyle, W.R., Campbell, R.K., Myers, R.V., Bernard, M.P., Han, Y., Wang, X., 1994. Co-evolution of ligand-receptor pairs. Nature 368, 251-255.

Noce, T., Ando, H., Ueda, T., Kubokawa, K., Higashinakagawa, T., Ishii, S., 1989. Molecular cloning and nucleotide sequence analysis of the putative cDNA for the precursor molecule of the chicken LH-beta subunit. J. Mol. Endocrinol. 3, 129-137.

Padmanabhan, V., Chappel, S.C., Beitins, I.Z., 1987. An improved in vitro bioassay for follicle-stimulating hormone (FSH): suitable for measurement of FSH in unextracted human serum. Endocrinology 121, 1089-1098.

Pierce, J.G., Parsons, T.F., 1981. Glycoprotein hormones: structure and function. Ann. Rev. Biochem. 50, 465-495.

Quérat, B., Sellouk, A., Salmon, C., 2000. Phylogenetic analysis of the vertebrate glycoprotein hormone family including new sequences of sturgeon (Acipenser baeri) beta subunits of the two gonadotropins and the thyroid-stimulating hormone. Biol. Reprod. 63, 222228.

Quérat, B., Tonnerre-Doncarli, C., Genies, F., Salmon, C., 2001. Duality of gonadotropins in gnathostomes. Gen. Comp. Endocrinol. 124, 308-314.

Quérat, B., Arai, Y., Henry, A., Akama, Y., Longhurst, T.J., Joss, J.M., 2004. Pituitary glycoprotein hormone beta subunits in the Australian lungfish and estimation of the relative evolution rate of these subunits within vertebrates. Biol. Reprod. 70, 356-363.

Ryan, R.J., keutmann, H.T., Charlesworth, M.C., McCormick, D.J., Milius, R.P., Calvo, F.O., Vutyavanich, T., 1987. Structure-function relationships of gonadotropins. In: Recent progress in Hormone Research Vol. 43. Academic Press, pp. 383-417. 
Sairam, M.R., Seidah, N.G., Chretien, M., 1981. Primary structure of the ovine pituitary follitropin beta-subunit. Biochem. J. 197, 541-552.

Saito, A., Kano, Y., Suzuki, M., Tomura, H., Takeda, J., Tanaka, S., 2002. Sequence analysis and expressional regulation of messenger RNAs encoding beta subunits of follicle-stimulating hormone and luteinizing hormone in the red-bellied newt, Cynops pyrrhogaster. Biol. Reprod. 66, 1299-1309.

Schally, A.V., Arimura, A., Kastin, A.J., Matsuo, H., Baba, Y., Redding, T.W., Nair, R.M., Debeljuk, L., White, W.F., 1971. Gonadotropin-releasing hormone: one polypeptide regulates secretion of luteinizing and follicle-stimulating hormones. Science 173, 10361038.

Schally, A.V., Redding, T.W., Matsuo, H., Arimura, A., 1972. Stimulation of FSH and LH release in vitro by natural and synthetic $\mathrm{LH}$ and FSH releasing hormone. Endocrinology 90, 1561-1567.

Schmidt, A., Gromoll, J., Weinbauer, G.F., Galla, H.J., Chappel, S., Simoni, M., 1999. Cloning and expression of cynomolgus monkey (Macaca fascicularis) gonadotropins luteinizing hormone and follicle-stimulating hormone and identification of two polymorphic sites in the luteinizing hormone beta subunit. Mol. Cell. Endocrinol. $156,73-83$.

Shen, S.T., Yu, J.Y.L., 1991. A rapid and sensitive in vitro bioassay of follicle stimulating hormone: estradiol-17 $\beta$ formation by dispersed seminiferous tube cells from immature rats. Zool. Sci. 8, 733-742.

Shen, S.T., Yu, J.Y.L., 2002. Cloning and gene expression of a cDNA for the chicken follicle-stimulating hormone (FSH)-beta-subunit. Gen. Comp. Endocrinol. 125, 375-386.

Sugino, H., Bousfield, G.R., Moore Jr., W.T., Ward, D.N., 1987. Structural studies on equine glycoprotein hormones. Amino acid sequence of equine chorionic gonadotropin beta-subunit. J. Biol. Chem. 262, 8603-8609.

Suzuki, K., Kawauchi, H., Nagahama, Y., 1988. Isolation and characterization of subunits from two distinct salmon gonadotropins. Gen. Comp. Endocrinol. 71, 302-306.
Tsai, P.S., Licht, P., 1993. GnRH-induced desensitization of in vitro luteinizing hormone secretion in the turtle, Trachemys scripta. Gen. Comp. Endocrinol. 89, 238-247.

Van Damme, M.P., Robertson, D.M., Marana, R., Ritzen, E.M., Diczfalusy, E., 1979. A sensitive and specific in vitro bioassay method for the measurement of follicle-stimulating hormone activity. Acta Endocrinol. (Copenh) 91, 224-237.

Virgin, J.B., Silver, B.J., Thomason, A.R., Nilson, J.H., 1985. The gene for the beta subunit of bovine luteinizing hormone encodes a gonadotropin mRNA with an unusually short $5^{\prime}$-untranslated region. J. Biol. Chem. 260, 7072-7077.

Weil, C., Bougoussa-Houadec, M., Gallais, C., Itoh, S., Sekine, S., Valotaire, Y., 1995. Preliminary evidence suggesting variations of GtH1 and GtH2 mRNA levels at different stages of gonadal development in rainbow trout, Oncorhynchus mykiss. Gen. Comp. Endocrinol. $100,327-333$.

Yoshiura, Y., Kobayashi, M., Kato, Y., Aida, K., 1997. Molecular cloning of the cDNAs encoding two gonadotropin beta subunits (GTH-I beta and -II beta) from the goldfish, Carassius auratus. Gen. Comp. Endocrinol. 105, 379-389.

Yu, J.Y.L., Namike, H., Gorbman, A., 1979. Rat gonadotropin release stimulated in vitro by GnRH-depleted rat brain extracts. Neuroendocrinology 29, 54-65.

Yu, J.Y.L., Shen, S.T., Liu, C.T., Weng, C.F., Peng, H.K., Liu, F.K., 1995. Comparative effects of avian and picine gonadotropins on gonadal steroidogenesis, and of avian and picine pituitaries on induction of spermiation and ovulation in the loach and white silver carp. Aquaculture 135, 59-72.

Yu, J.Y.L., Shen, S.T., Yang, W.H., Papkoff, H., Ishii, S., 1996. Comparative effects of diverse vertebrate gonadotropins on estradiol-17 beta formation in vitro in an immature rat Sertoli cell bioassay. Gen. Comp. Endocrinol. 104, 253-261.

Yu, J.Y.L., Wang, L.M., 1987. Comparative effects of diverse vertebrate gonadotropins on androgen formation in vitro from testes of rooster and mice. Biol. Reprod. 36, 816-824. 